\title{
A new route to functionally-substituted tetrazines
}

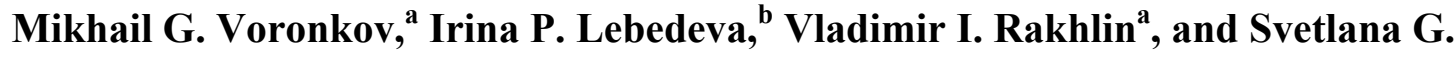 \\ D'yachkova ${ }^{\text {b }}$ \\ ${ }^{a}$ A.E. Favorsky Irkutsk Institute of Chemistry Siberian Branch of the Russian Academy of \\ Sciences, 1 Favorsky St., Irkutsk, 664033 Russian Federation \\ ${ }^{b}$ Irkutsk State Technical University, 83 Lermontov St., Irkutsk, 664033 Russian Federation \\ E-mail: vir@irioch.irk.ru; $\underline{\text { dsg@irk.ru }}$
}

The paper is dedicated to the $70^{\text {th }}$ birthday of our friend Professor Vladimir Minkin who has contributed a great deal to organic and physical-organic chemistry

(received 29 Nov 04; accepted 10 Feb 05; published on the web 03 Mar 05)

\begin{abstract}
Ethylthio and isopropylthio chloroacetylenes react with dimethylhydrazine in ether at room temperature to form 1,1,4,4-tetramethyl-3,6-bis-[(alkylythio)methyl]-1,4-dihydro-1,2,4,5tertazinium-1,4-dichlorides in 67 and $80 \%$ yield.
\end{abstract}

Keywords: (Alkylthio)chloroacetylenes, dimethylhydrazine, tetrazines

\section{Introduction}

(Alkylthio)chloroacetylenes react readily with $N-, O$ - and $S$ - mono- and bifunctional nucleophiles ${ }^{1}$ to afford substituted polyfunctional unsaturated compounds including heterocyclic ones. For instance, the reactions with alkylenediamines, ${ }^{2}$ 2-hydroxyethylamine ${ }^{3} 2$-hydroxy- $N, N$ dimethylamine, ${ }^{4}$ thiosemicarbazones, ${ }^{5}$ proceed by nucleophilic substitution of the acetylenic chlorine forming ynammonium salts which further undergo cyclization. In this way it was possible to obtain imidazole, oxazolone, oxazolidine, oxazine, and thiazole derivatives which, in certain cases, display effective complex-forming properties or high antimicrobial and antitumor activity. The reactions of (alkylthio)chloroacetylenes with nucleophiles open up new routes to new classes of polyfunctional acyclic and heterocyclic compounds and allow investigation of the nucleophilic substitution at $s p$-hybridized carbon atoms. 


\section{Results and Discussion}

The reaction of (alkylthio)chloroacetylenes 1 with dimethylhydrazine, a large-tonnage product within the chemical industry, is not well understood. Prior to our investigation the literature on the reaction of haloacetylenes with hydrazine and its derivatives was limited to a brief note describing the reaction of bromoethynyl(aryl)ketones with $N, N$-dimethylhydrazine leading to further polymerization and hydrobromination of the intermediate ethynylhydrazines. ${ }^{6}$ The bidentate nucleophilic character of $N, N$-dimethylhydrazine $(\mathrm{DMH})$ and the presence of two $\mathrm{C}_{s p}$ atoms in the acetylene $\mathbf{1}$ makes prediction of the product composition difficult. We have shown that (ethylthio) and (iso-propylthio) chloroacetylenes 1a,b react readily with an equimolar amount of DMH in ether at $20-22^{\circ} \mathrm{C}$ to afford 1,1,4,4,-tetramethyl-3,6-bis-[(alkylthio)methyl]1,4-dihydro-1,2,4,5-tetrazinium-1,4-dichlorides $\mathbf{2 a , b}$ in 67 and 80\% yield, respectively (Scheme 1).

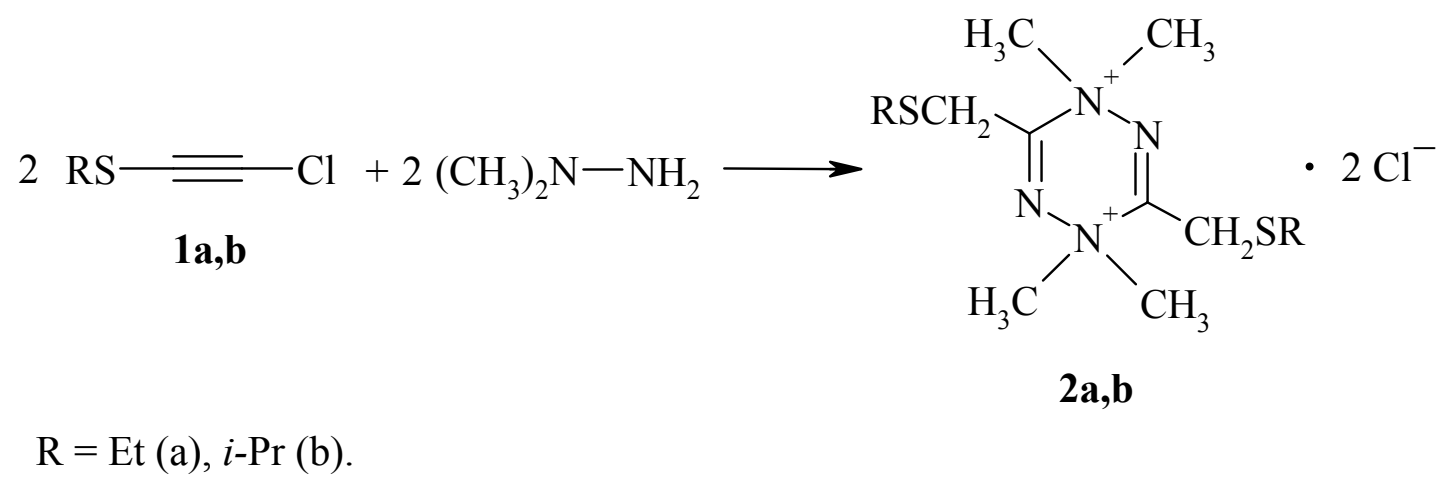

\section{Scheme 1}

Compounds 2a,b are white crystalline substances soluble in water, DMSO and ethanol. In the ${ }^{13} \mathrm{C}$ NMR spectra of $\mathbf{2 a}, \mathbf{b}$ there are signals of carbon atoms of alkylthio-, $\mathrm{CH}_{3}-\mathrm{N}^{+}$and exocyclic alkylthiomethylene $\left(\mathrm{SCH}_{2}\right)$ groups, as well as a signal at $128 \mathrm{ppm}$, which was assigned to two magnetically equivalent carbon atoms $(\mathrm{C}=\mathrm{N})$ in the tetrazine cycle ${ }^{6,7}$ Apart from the alkylthio proton signals, the ${ }^{1} \mathrm{H}$ NMR spectra of compounds $\mathbf{2 a}, \mathbf{b}$ show two singlet signals at $\sim 2.7$ and 3.6 ppm corresponding to $\mathrm{SCH}_{2}$ - and $\mathrm{CH}_{3} \mathrm{~N}$ - group protons, respectively. In the IR spectra of the dichlorides 2a,b display absorption bands at $1600 \mathrm{~cm}^{-1}$ from the $\mathrm{C}=\mathrm{N}$ stretching vibrations . Their ionic character was confirmed by mercurimetric titration which indicated the presence of two chloride-ions per mole of compound.

Formation of tetrazines $\mathbf{2 a , b}$ in the reaction under consideration (Scheme 1) can be rationalized by Scheme 2 including the nucleophilic attack of the tertiary nitrogen atom of dimethylhydrazine at the $\mathrm{C}_{s p}$ carbon atom of chloroacetylenes 1a,b leading to substitution of the halogen atom and formation of ethynylammonium salts $\mathbf{3 a}, \mathbf{b}$. The latter dimerize into alkylthiomethylidenetetrazines $\mathbf{4 a , b}$ which after prototropic isomerization give tetrazinium-1,4dichlorides 2a,b. 

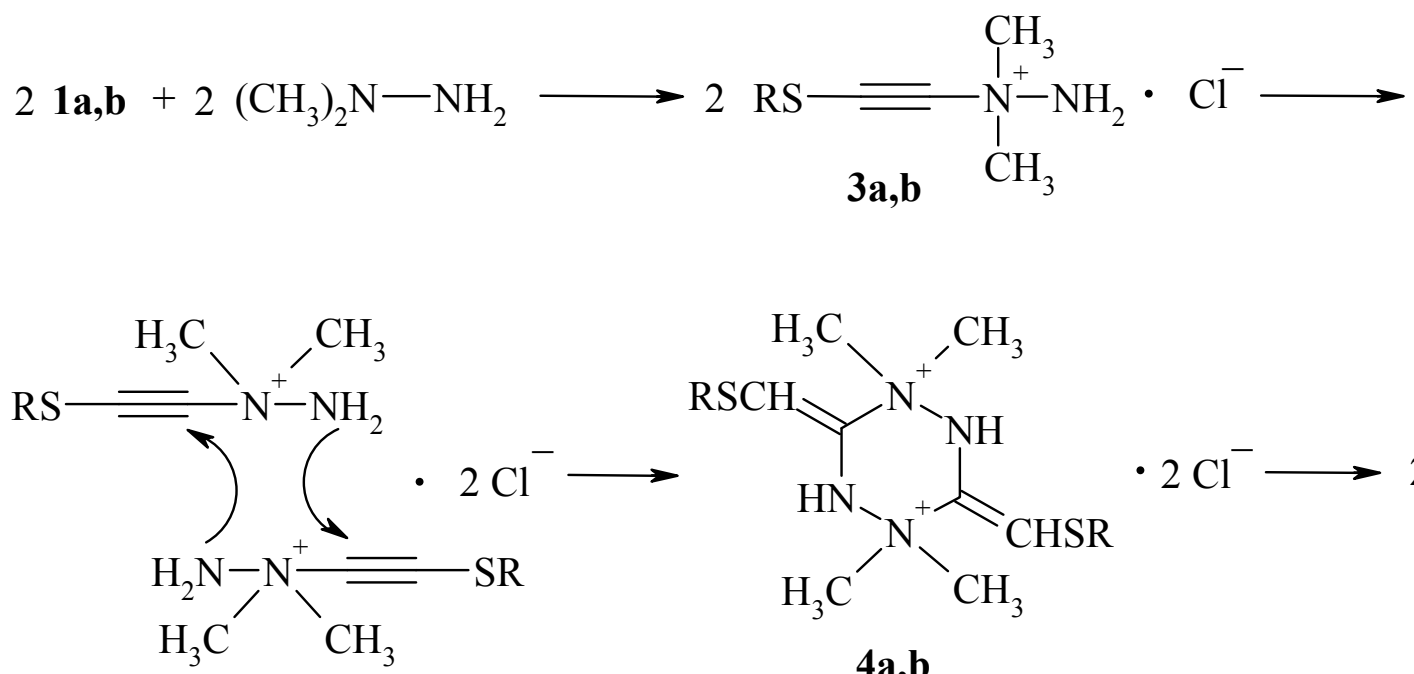

Scheme 2

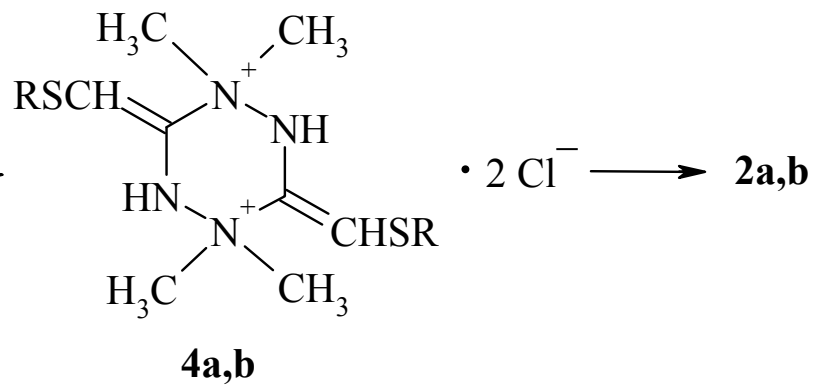

Thus, the reaction of (ethylthio) and (iso-propylthio) chloroacetylenes with $\mathrm{N}, \mathrm{N}$ dimethylhydrazine allows the elaboration of a new synthetic approach to functionally substituted tetrazines. The representatives of this class of compounds have for long time attracted the attention of research chemists due to their high and diverse biological activity. ${ }^{8}$

\section{Experimental Section}

General Procedures. IR Spectra were recorded on a Specord IR-75 spectrometer in microlayer. ${ }^{1} \mathrm{H}$ and ${ }^{13} \mathrm{C}$ NMR spectra were run on a Bruker DPX-400 (400 MHz for ${ }^{1} \mathrm{H}$ and $100 \mathrm{MHz}$ for ${ }^{13} \mathrm{C}$ ) in DMSO, TMS as internal standard.

GLC analysis was carried out on a Tsvet-500 chromatograph, glass columns $3 \mathrm{~m} \times 4 \mathrm{~mm}$, sorbent Inerton-super 0.125-0.150 mm impregnated with 10\% PMS-1000, katharometer, helium as gas carrier.

\section{1,1,4,4-Tetramethyl-3,6-bis-[(ethylthio)methyl]-1,4-dihydro-1,2,4,5-tetrazinium-1,4-}

dichloride (2a). To a solution of $2.50 \mathrm{~g}(0.042 \mathrm{~mol}) \mathrm{DMH}$ and $100 \mathrm{ml}$ of dry ether a solution of $5.06 \mathrm{~g}(0.042 \mathrm{~mol})$ of acetylene $1 \mathrm{a}$ in $20 \mathrm{ml}$ of dry ether was added drop wise on stirring for $30 \mathrm{~min}$. The reaction proceeded exothermally. The reaction temperature was kept at $20-22^{\circ} \mathrm{C}$ using external cooling. After the addition of the acetylene solution, the reaction mixture was stirred at $20-22^{\circ}$ for further $8 \mathrm{~h}$. Then, the precipitate was filtered off, washed with dry diethyl ether $(3 \times 10 \mathrm{ml})$ and dried in vacuum. $5.10 \mathrm{~g}(67 \%)$ of compound $2 \mathrm{a}$ was obtained as a white crystalline substance, m.p. $77-79^{\circ} \mathrm{C}$. Anal. calcd. for $\mathrm{C}_{12} \mathrm{H}_{26} \mathrm{Cl}_{2} \mathrm{~N}_{4} \mathrm{~S}_{2}, \%$ : C 39.88; $\mathrm{H} \mathrm{7.20;} \mathrm{Cl}$ 19.67; N 15.51; S 17.73. Found, \%: C, 39.57; H, 7.28; Cl, 19.81; N, 15.60; S, 17.53. IR (KBr), $\mathrm{cm}^{-1}:$ 3056, 2988, $2924[v(\mathrm{C}-\mathrm{H})], 2800-2600$ [v(ammonium band $\left.)\right], 1626[v(\mathrm{C}=\mathrm{N})] .{ }^{1} \mathrm{H}$ NMR, $\delta$, 
ppm: $1.25 \mathrm{t}\left(6 \mathrm{H}, \mathrm{CH}_{3}\right), 2.74 \mathrm{~s}\left(4 \mathrm{H}, \mathrm{SCH}_{2}\right), 2.96 \mathrm{q}\left(4 \mathrm{H}, \mathrm{CH}_{2} \mathrm{~S}\right), 3.59 \mathrm{~s}\left(12 \mathrm{H}, \mathrm{CH}_{3} \mathrm{~N}^{+}\right) .{ }^{13} \mathrm{C} \mathrm{NMR}$, $\delta_{\mathrm{C}}, \mathrm{ppm}: 16.15\left(\underline{\mathrm{CH}}_{3}\right), 27.16\left(\underline{\mathrm{CH}}_{2} \mathrm{~S}\right), 39.50\left(\mathrm{~S}_{\underline{C}}{ }_{2}\right), 59.95\left(\underline{\mathrm{CH}}_{3} \mathrm{~N}^{+}\right), 128.66(\underline{\mathrm{C}}=\mathrm{N})$.

1,1,4,4-Tetramethyl- 3,6-bis-[(iso-propylthio)methyl] -1,4-dihydro-1,2,4,5-tetrazinium-1,4dichloride (2b). Obtained by the above described procedure from $2.05 \mathrm{~g}(0.034 \mathrm{~mol})$ of $\mathrm{DMH}$ and $4.60 \mathrm{~g}(0.034 \mathrm{~mol})$ of acetylene $\mathbf{1 b}$. Yield of 2 b $5.30 \mathrm{~g}(80 \%)$. M.p.. 80-81 ${ }^{\circ} \mathrm{C}$. Anal. calcd. for $\mathrm{C}_{14} \mathrm{H}_{30} \mathrm{Cl}_{2} \mathrm{~N}_{4} \mathrm{~S}_{2}, \%$ : C 43.18; $\mathrm{H}$ 7.71; $\mathrm{Cl} 18.25 ; \mathrm{N} \mathrm{14.39;} \mathrm{S} \mathrm{16.45.} \mathrm{Found,} \mathrm{\% :} \mathrm{C,} \mathrm{43.32;} \mathrm{H}$, 7.52; Cl, 18.39; N, 14.60; S, 16.53. IR (KBr), $\mathrm{cm}^{1}: 3076,2988,2920[v(\mathrm{C}-\mathrm{H})], 2800-2600$ [v(ammonium band $)], 1632[v(\mathrm{C}=\mathrm{N})] .{ }^{1} \mathrm{H} \mathrm{NMR}, \delta, \mathrm{ppm}: 1.36 \mathrm{~d}\left(12 \mathrm{H}, \mathrm{CH}_{3}\right), 2.74 \mathrm{~s}\left(4 \mathrm{H}, \mathrm{CH}_{2} \mathrm{~S}\right)$, $3.54 \mathrm{q}(2 \mathrm{H}, \mathrm{CH}), 3.60 \mathrm{~s}\left(12 \mathrm{H}, \mathrm{CH}_{3} \mathrm{~N}^{+}\right) .{ }^{13} \mathrm{C} \mathrm{NMR}, \delta_{\mathrm{C}}, \mathrm{ppm}: 23.65\left(\mathrm{CH}_{2} \mathrm{~S}\right), 23.82\left(\underline{\mathrm{CH}}_{3}\right), 37.74$ $(\underline{\mathrm{C}} \mathrm{H}), 57.38\left(\underline{\mathrm{CH}_{3} \mathrm{~N}^{+}}\right), 127.23(\underline{\mathrm{C}}=\mathrm{N})$.

\section{Acknowledgements}

The work has been performed with financial support of the Presidium of the Siberian Branch of the Russian Academy of Sciences, Integration Project No. 114 and the Fund of the President of the Russian Federation (Science Schools), Grant 1129.2003.3

\section{References}

1. Mirskova, A.N.; Seredkina, S.G. (D’yachkova S.G.); Voronkov, M.G. Sulfur Rep. 1989, 9, 75 .

2. Mirskova, A.N.; Seredkina, S.G.; Kalikhman, I. D., Voronkov, M.G.; Bannikova, O.B. Izv. Akad. Nauk SSSR, Ser. Khim. 1989, 4, 906.

3. Mirskova, A.N.; Seredkina, S.G.; Kukharev, B. F.; Bannikova, O.B. Zh. Org. Khim. 1990, $26,1,201$.

4. Mirskova, A.N.; Seredkina, S.G.; Voronkov, M.G.; Kalikhman, I. D.; Bannikova, O.B. Zh. Org. Khim. 1985, 21, 3, 503.

5. D’yachkova, S.G.; Nikitina, E. A.; Larina, L. I.; Ushakov, P. E.; Gusarova, N. K.; Sinegovskaya, L.M.; Trofimov, B.A. Synthesis 2002, 7, 916.

6. Elokhina, V. N.; Nachmanovich, A. S.; Larina, L. I.; Shishkin, O. V.; Baumer, B. H.; Loparev, V. A. Izv. Rus. Akad. Nauk, Ser. Khim. 1999, 8, 1536.

7. Levy, G. C.; Nelson, G. L. Carbon-13 Nuclear Magnetic Resonance for Organic Chemists; John Wiley \& Sons: New York, 1972.

8. Wilson, C. O.; Gisvold, O.; Doerge, R. F. Textbook of Medicinal and Pharmaceutical Chemistry; Pitman: London, 1966; p 237. 